to those suggested by the Library Association, and reported in Nature (218, 1196; 1968), although they are much less positive and, because of the functions of the two associations, different emphasis is placed on different aspects of the problem. Like the Library Association, Aslib wants to see a coordinated National Library Administration (what the LA calls a National Library Service). This should cover the present library departments of the British Museum, the National Reference Library of Science and Invention, the National Lending Library and the National Central Library, but should not include the Science Museum Library. The administration is seen as a subunit of a future National Information and Library Authority, supported probably by the Department of Education and Science. As to the location of the National Library, the memorandum suggests that central London is the best place for either a unified system (reference and lending), or for the reference function of a dual system. The future of Aslib itself is seen alongside the National Library where its resources and experience could be used for the study and development of operational systems. This suggestion agrees with one made in the Library Association report on Scientific Library Services (see Nature, 21\%, 216; 1968).

The Aslib memorandum is a rather inconclusive document, principally because it admits to the lack of knowledge on user requirements and cost and effectiveness relationships of the possible organizational structures. And Aslib seems to disagree with the Library Association about the linkage of the museum collections and the library departments of the British Museum. The librarians came out strongly for the separation of the antiquities and the books, but Aslib seems to be completely uncommitted.

\section{Security at Stonehenge}

The prehistoric Indian dwellings in the Mesa Verda National Park in Colorado and rock formations in several other National Parks, including Bryce Canyon in the south-west of America, are said to be suffering damage from sonic booms-although, to be fair, the Defense Department vigorously denies any connexion between the damage that is undoubtedly occurring and sonic booms caused by military aircraft. In Britain, the monuments under the care of the Ministry of Public Building and Works face damage of a much more mundane kind-vandalism, souvenir hunting and casual damage by visitors. Like any other curator, the ministry has to balance the legitimate demands of the public to see its monuments with the need to preserve them for posterity. The system of having a curator on the site when it is open, and prohibiting access at night, provides adequate protection for most of the monuments, but the exception is Stonehenge, which is a source of continual problems.

The turf at Stonehenge is relatively safe, now that the Druids have given up their former practice of burying ashes under it, and during the day with a curator in attendance the monument is fairly safe. The children and adults who clamber over the stones behind the curator's back may give the impression of literally treading Stonehenge into the ground, but, according to the ministry, they do little real damage. It is during the night that the real harm is done. The ministry is loth to fence Stonehenge off for aesthetic reasons - and to do so would be to admit that all the existing protection was inadequate. For some curious reason, however, Stonehenge attracts university rag committees, supporters of the Campaign for Nuclear Disarmament and people who enjoy spending their evenings painting the stones with slogans. The last case was on the night of February 20-21 this year, when seven stones were daubed with yellow paint. The problem is that the paint penetrates so deeply that cleaning would cause irreparable damage to the surface of the monument. As a result of this continual vandalism the ministry has, since February, started new security measures during the night and even stricter precautions are being planned. These, like all the best sccurity arrangements, must obviously remain secret.

Preventing the daubing of Stonehenge is not, of course, simply a matter of aesthetics. As recently as 1956 the very faint carving of a dagger was discovered by a visitor who chanced to look up at one of the stones in unusual light conditions. If there are any other such carvings, they could be important clues to the origin of Stonehenge, which still remains obscure.

\section{Astronomical Hardware}

OPTICAL astronomers are turning increasingly to the techniques of instrumentation to get the most from

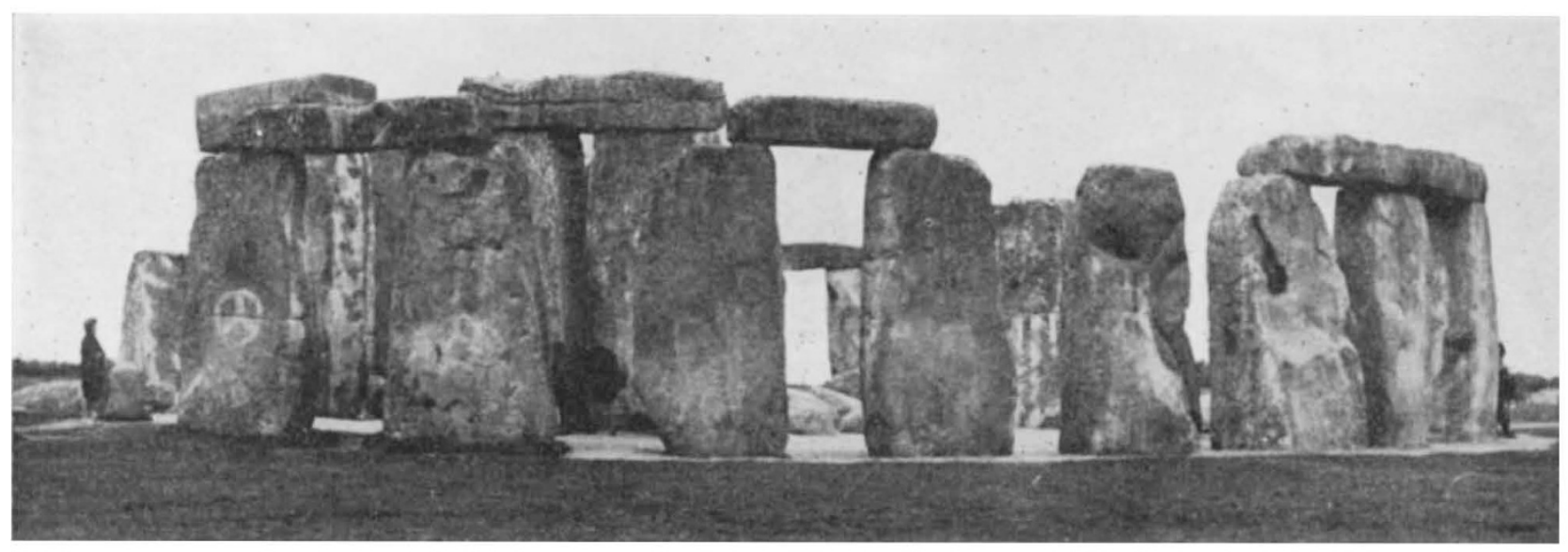

